\title{
Hotel Recommendation System Using SAW (Simple Additive Weighting) and TOPSIS (The Technique for Order of Preference by Similarity to Ideal Solution) Method
}

\author{
Aditiya Heramawan'*, Evan ${ }^{2)}$ \\ 1)2) Buddhi Dharma University \\ Tangerang, Indonesia \\ 1) adtlotus@gmail.com \\ 2) evan hadiwinata@yahoo.com
}

\begin{tabular}{|c|c|}
\hline Article history: & Abstract \\
\hline $\begin{array}{l}\text { Received } 28 \text { February } 2019 ; \\
\text { Revised } 10 \text { March } 2019 ; \\
\text { Accepted } 11 \text { April } 2019 ; \\
\text { Available online } 30 \text { April } 2019\end{array}$ & $\begin{array}{l}\text { Tourism is one of the important economic sectors in Indonesia that needs to be } \\
\text { developed. This is based on data of the number of tourist visits from "Kementrian } \\
\text { Pariwisata Republik Indonesia" website that the number of tourists in Indonesia is }\end{array}$ \\
\hline $\begin{array}{l}\text { Decision Support System } \\
\text { Hotel Recomendation } \\
\text { SAW } \\
\text { TOPSIS }\end{array}$ & $\begin{array}{l}\text { tourist visits from various places, makes many entrepreneurs are competing to } \\
\text { establish a hotel as a place of business with variety of price, class, facility and } \\
\text { service. Then, the growth of the hotels became very rapid. With so many choices } \\
\text { of the hotels, of course it will cause a problem for tourists to decide which hotel is } \\
\text { suitable with the desired criteria. Development of information technology in this } \\
\text { era of globalization, technology should be utilized to solve this problem as a } \\
\text { decision support system that can recommend which hotel is the most suitable from } \\
\text { the tourist desires. Hotel data to be used in this research comes from hotel search } \\
\text { site. The methods used for this decision support system are SAW and TOPSIS } \\
\text { methods. Reason for using this method is because SAW has the ability to assess } \\
\text { more accurately because it is based on criteria and the computation of TOPSIS } \\
\text { method is efficient and fast. Criteria used on choosing the hotel are price, facilities } \\
\text { and class. The results of this research has been generated as a web-based application } \\
\text { for hotel recommendation. Based on the test results of this hotel recommendation } \\
\text { system application, this application works as expected. }\end{array}$ \\
\hline
\end{tabular}

\section{INTRODUCTION}

Indonesia is a country consisting of many islands which have their own beauty and consist of various ethnic groups, languages, religions, cultures and customs. Due to this diversity, there are many places in Indonesia that can be used as tourist destinations and improve the tourism sector. Based on data from the Ministry of Tourism of the Republic of Indonesia, on foreign tourist visits in January 2016 there were 814,303 people visiting Indonesia and an increase of $36.06 \%$ in January 2017 there were 1,107,968 people visiting Indonesia. There is also data on domestic tourist visits in 2011 as many as 236,752,000 people traveled, in 2012 as many as 245,290,000 people and in $2013250,036,000$ people. It can be seen that the number of domestic and foreign tourists has increased [3].

Along with the large number of tourist visits from various places, requires that all facilities that support the tourism sector need to be developed again, one of which is lodging or hotel facilities. Many entrepreneurs are competing to set up hotels as places of business with varied prices, classes, facilities and services. Based on data obtained from BPS (Central Bureau of Statistics), the number of star hotels in Indonesia in 2014 was 1,996 hotels, in 2015 it increased to 2,197 hotels and in 2016 increased to 2,387 hotels. Of the number of star hotel rooms recorded in 2014 as many as 195,886 rooms, increased in 2015 to 217,474 rooms and increased in 2016 to 233,007. Of the number of star hotel beds recorded in 2014 as many as 295,426 beds, increased in 2015 to 322,590 beds and increased in 2016 to 346,959 beds [1]. 
The many choices of this hotel will certainly make it difficult for consumers or tourists to determine the hotel that fits the desired criteria. Because of this, tourists are often wrong in choosing a hotel, especially if until tourists come from far to the hotel location but not according to the criteria of the tourist of course this is a problem for tourists. Another common problem that occurs is that most tourists who use the internet for hotel searches are only fixated on the keywords given, for example, tourists search for hotels by entering the keyword "cheap hotel" and finally searches displaying hotel listings at low prices without considering criteria - other criteria such as good or not the condition of the hotel, the suitability of hotel facilities, and so on.

The SAW method (Simple Additive Weighting) is known to have advantages compared to other decision-making methods, namely its ability to be more precise in conducting assessments because it is based on preference weights and predetermined criteria values [2]. The TOPSIS (Technique for Order Preference by Similarity to Ideal Solution) method is also known to have advantages because the concept is simple, easy to understand, efficient computing and capable of measuring the relative performance of several decision alternatives in mathematical form simple[8].

Along with the development of information technology in this globalization era, technology needs to be utilized and applied, one of which is as a decision support system to overcome mistakes in choosing hotels. Decision support systems are expected to be able to recommend hotels in accordance with the criteria that have been determined precisely and effectively to be addressed to tourists. Criteria used as hotel selection criteria are price, facilities and class.

Research purposes:

1. Provide hotel recommendations that match the criteria of tourists.

2. Applying the SAW and TOPSIS methods to the hotel recommendation system to make it easier for tourists to determine the desired hotel according to the criteria.

\section{RELATED WORKS}

\section{Decision Support System}

Decision support system is a computer-based system consisting of three interconnected components, namely a language system that is useful as a communication link between users and other decision support system components, knowledge systems that are useful as a place of storage or repository of knowledge in a decision support system or as data or as a procedure, and a problem processing system that is useful for determining decision making. Decision support systems are usually made in order to support or provide solutions to problems and for opportunities [5].

\section{Tourism}

Tourism is an activity of traveling with the aim of gaining pleasure, seeking satisfaction, knowing something, improving health, enjoying sports or resting, performing tasks, making pilgrimages, etc., is not an activity that has just been done by humans today. According to the broad definition tourism is a journey from one place to another, is temporary, carried out individually or in groups, as an effort to find balance or harmony and happiness with the environment in social, cultural, natural and scientific dimensions. A person can travel in various ways for different reasons[9].

\section{Hotel}

Hotel is one of the businesses engaged in services to seek profits through a service to guests who stay overnight such as front office, household, food and drink services, mice, and recreation. With the hospitality business, there are many things offered to guests. All that is offered is a hotel product. The hotel products can be divided into several forms such as hotel rooms, food and beverage services, restaurants and other facilities[10].

\section{SAW (Simple Additive Weighting)}

The SAW method is also known as the weighted sum method. The basic concept of this method is to find a weighted sum of performance ratings on each alternative of all attributes. The SAW method requires the process of normalizing the decision matrix (X) to a scale that can compare with all available alternative ratings [2]. The stages in the SAW method are as follows:

1. Determine alternatives

$$
A=\{A 1, A 2, \ldots . ., A i\}
$$

2. Determine criteria that will be used as a reference in decision making

$$
C=\{C 1, C 2, \ldots . ., C j\}
$$

3. Determine the suitability rating of each alternative on each criterion. 
4. Determine the preference weight or level of importance (W) of each criterion.

$W=\{W 1 W 2 W 3 \ldots \ldots \ldots W\}$

5. Make a decision matrix based on criteria $(\mathrm{Cj})$, then normalize the matrix based on equations adjusted for the type of attribute (benefit attribute or cost attribute) so that the normalized matrix $r$ is obtained.

$$
\begin{aligned}
& r_{i j}=\frac{x_{i j}}{\operatorname{Max}\left(x_{i j}\right)} \text { if } \mathrm{j} \text { is an attribute of benefits. } \\
& r_{i j}=\frac{\operatorname{Min}\left(x_{i j}\right)}{x_{i j}} \text { if } \mathrm{j} \text { is the cost attribute. }
\end{aligned}
$$

Where $r_{i j}$ is the normalized performance rating of the alternative Ai in the $\mathrm{Ci}$ attribute; $\mathrm{i}=1,2,3, \ldots, \mathrm{m}$ and $\mathrm{j}=1,2,3$, ..., m.

1. $\operatorname{Max} X_{i j}=$ the biggest value of each criterion $i$.

2. $\operatorname{Min} \mathrm{X}_{\mathrm{ij}}=$ the smallest value of each criterion $\mathrm{i}$.

3. $\mathrm{X}_{\mathrm{ij}}=$ Value of attributes that are owned by each criterion.

4. Benefit $=$ If the biggest value is the best.

5. Cost $=$ If the smallest value is the best.

Alternative preference value ( $\mathrm{Vi})$ is given as:

$$
V_{i}=\sum_{j=1}^{n} w_{j} r_{i j}
$$

A higher $\mathrm{V}$ value indicates that the alternative $\mathrm{Ai}$ is more chosen.

1. $\mathrm{Vi}=$ Ranking for each alternative.

2. $\mathrm{Wj}=$ Value of ranking weight (of each criterion).

3. $\quad$ rij $=$ Normalized performance rating value

Simple Additive Weighting method has advantages compared to other decision support system methods, namely its ability to make assessments more precisely because it is based on the criteria value and the level of importance needed. In the SAW method, the best alternative selection is done from a number of alternatives, then a ranking process is carried out in which the sum of the weighted values of all criteria is added after determining the weight values of each criterion [5],

\section{Metode TOPSIS (The Technique for Order of Preference by Similarity to Ideal Solution)}

Technique for Other Preferences by Similarity to Ideal Solution (TOPSIS) is part of the DSS method developed by Yoon and Hwang (1981). This method is the chosen alternative method that has the closest distance from the positive ideal solution and the farthest from the negative ideal solution. Then the choice will be ranked based on value, then the alternative that has the shortest distance along with the ideal positive solution is a best alternative. Another term, that alternative has a higher value and is good to use or take as a decision [6].

The following are the steps of the TOPSIS method [6].

1. TOPSIS requires a performance rating for each $\mathrm{Ai}$ alternative on normalized $\mathrm{Cj}$ criteria, explained in Equation (1).

$$
r_{i j}=\frac{x_{i j}}{\sqrt{\sum_{i=1}^{m} x_{i j}^{2}}}
$$

with $\mathrm{i}=1,2, \ldots, \mathrm{m}$; and $\mathrm{j}=1,2, \ldots, \mathrm{n}$ where:

$\mathrm{r}_{\mathrm{ij}}=$ normalized matrix [i] [j]

$\mathrm{x}_{\mathrm{ij}}=$ decision matrix $[\mathrm{i}][\mathrm{j}]$

2. Giving a weighted value normalized decision matrix according to the required criteria, explained in Equation (2).

$$
y_{i j}=w_{i} r_{i j}
$$

with $\mathrm{i}=1,2, \ldots, \mathrm{m}$; and $\mathrm{j}=1,2, \ldots, \mathrm{n}$ where:

yij $=$ weighted normalized matrix [i] [j]

wi $=$ vector weight $[\mathrm{i}]$ 
3. Calculating the highest value, then you can find the positive ideal solution $(\mathrm{A}+)$ described in Equation (3) Conversely the lowest value can be found for the ideal negative solution (A-) described in Equation (4).

where:

$$
\begin{aligned}
& A^{+}=\left(y_{1}^{+}, y_{2}, \ldots y_{m}\right) \\
& A^{-}=\left(y_{1}^{-}, y_{2}, \ldots y_{m}\right)
\end{aligned}
$$

$$
\begin{gathered}
y j+=\max y i j, \text { if } j \text { is the profit attribute } \\
\text { min yij, if } j \text { is the cost attribute } \\
y j-=\min y i j, \text { if } j \text { is the profit attribute } \\
\max y i j, \text { if } j \text { is the cost attribute } \\
j=1,2, \ldots, n
\end{gathered}
$$

4. Finding the distance to the value of each alternative with a matrix of positive ideal solutions and a matrix of ideal negative solutions. The alternative distance to the positive ideal solution ( $\mathrm{Di}+$ ) is explained in Equation (5) while the alternative distance to the ideal negative solution (Di-) is explained in Equation (6).

$$
\begin{aligned}
& D_{i}^{+}=\sqrt{\sum_{i=1}^{n}\left(y_{i}^{+}-y_{i j}\right)^{2}} \\
& D_{i}^{-}=\sqrt{\sum_{i=1}^{n}\left(y_{i j}-y_{i}^{-}\right)^{2}}
\end{aligned}
$$

where:

$D_{i}^{+}=$Ai's alternative distance with a positive ideal solution

$y_{i}^{+}=$positive ideal solution [i]

$y_{i}^{-}=$negative ideal solution [i]

$\mathrm{y}_{\mathrm{ij}}=$ weighted normalization matrix $[\mathrm{i}][\mathrm{j}]$

5. After that, find Vi preference values in each alternative for the final calculation of the TOPSIS method, described in Equation (7).

$$
V_{i}=\frac{D_{i}^{-}}{D_{i}^{+}+D_{i}^{-}}
$$

where:

$\mathrm{Vi}=$ the closeness of each alternative to the ideal solution

$\mathrm{D}_{-} \mathrm{i}^{\wedge}+=$ alternative distance Ai with a positive ideal solution

$\mathrm{D}_{-} \mathrm{i}^{\wedge}-=$ alternative distance Ai with negative ideal solution

6. Ordering alternative results is in harmony with $\mathrm{V}$ values.

\section{API (Application Programming Interface)}

Application programming interface (API) is a documentation that consists of functions, classes, structures, interfaces and so on that are used to build applications or software. Through this API programmer can easily dismantle a software, then can be developed or integrated with other software. The API is also often referred to as an application liaison with another application that allows the programmer to use the system function. This process is managed through the operating system. The advantage of this API is that it allows an application with other applications to interact and connect with each other [7].

\section{METHOD}

The methodology used in designing this Hotel Recommendation System is SDLC (Lifecycle Development System) which has 7 Stages [4]:

1. Identify problems, opportunities and goals

At this stage, the author understands that there are problems that arise, namely problems in the selection of hotels and defining these problems in detail. The stages, namely:

a. Finding the existence of a problem, namely the problem of the difficulty in determining the hotel according to criteria and desires

b. Formulate problems, namely with the existence of these problems, the authors see the opportunity that this problem can be solved by making the application of hotel recommendations. The author also thinks about 
what methods can be applied to solve the problem and the authors find the SAW and TOPSIS methods can solve the problem.

c. Determine the purpose of making an application, namely by making a hotel recommendation application intended to be able to provide recommendations in accordance with the criteria of visitors.

2. Determine information requirements

At this stage the author establishes information requirements where the author analyzes the raw data on the hotel service provider's websitem and determines whether or not the information needed is needed which can be used as alternative data and criteria in selecting hotels.

3. Analyzing system requirements

At this stage the author invades RE (Requirement Elicitation) to several respondents to find out what things need to be included in the system.

4. Design the recommended system

a. Create a flowchart to arrange the process running from input, process, and output to the application of hotel recommendations to be more structured.

b. Model hotel recommendations using the SAW and TOPSIS methods

5. Develop software

Implement the trial in the form of a recommendation application

6. Test and maintain the system

Test and evaluate the application recommendations made.

7. Implementing the System

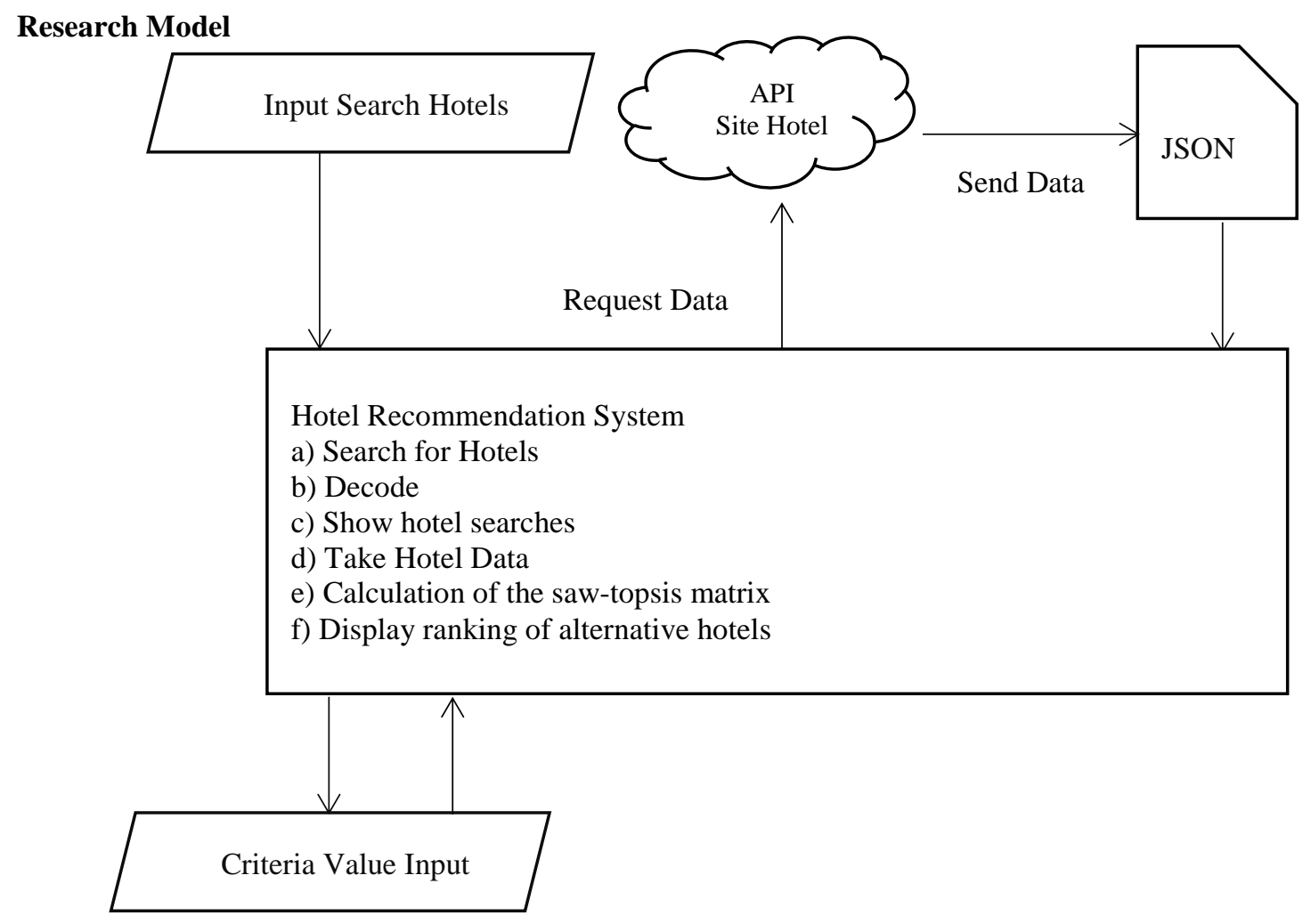

\section{Results}

\section{Criteria Data}

Of the several criteria used in these journals, the researcher considered which criteria were most widely used and also considered the availability of data for the criteria to be used. Final in this study the criteria used are:

1. Hotel Room Rental Prices (cost)

2. Hotel facilities (benefits)

3. Hotel Class (benefit) 
At each criterion value an alternative is weighted, where the value will be changed to fuzzy numbers, judged from 1 to 5 , i.e:

$1=$ Very Bad

$2=\mathrm{Bad}$

$3=$ Enough

$4=$ Good

$5=$ Very Good

Following are the weighting rules for each of the criteria to be described in table 1, table 2 and table 3

Table 1 Criteria Weighting Hotel Room Rental Prices (C1)

\begin{tabular}{|l|l|}
\hline \multicolumn{1}{|c|}{ Room Rental Prices $(\mathrm{C} 1)$} & Value \\
\hline $\mathrm{C} 1<=500.000$ & 1 \\
\hline $500.001<=\mathrm{C} 1<=1.000 .000$ & 2 \\
\hline $1.000 .001<=\mathrm{C} 1<=2.000 .000$ & 3 \\
\hline $2.000 .001<=\mathrm{C} 1<=5.000 .000$ & 4 \\
\hline $\mathrm{C} 1>=5.000 .001$ & 5 \\
\hline
\end{tabular}

Table 2 Facility Criteria Weighting (C2)

\begin{tabular}{|l|l|}
\hline Facilities $(\mathrm{C} 2)$ & Value \\
\hline $0-0.2$ & 1 \\
\hline $0.201-0.4$ & 2 \\
\hline $0.401-0.6$ & 3 \\
\hline $0.601-0.8$ & 4 \\
\hline $0.801-1$ & 5 \\
\hline
\end{tabular}

Table 3 Weighting of Hotel Class Criteria (C3)

\begin{tabular}{|l|l|}
\hline Hotel Class (C3) & Value \\
\hline 1 Star & 1 \\
\hline 2 Star & 2 \\
\hline 3 Star & 3 \\
\hline 4 Star & 4 \\
\hline 5 Star & 5 \\
\hline
\end{tabular}

The merging algorithm for Simple Additive Weighting (SAW) Method and Technique for Order Preference Method by Similarity to Ideal Solution (TOPSIS) on the system can be shown in the following flowchart. 


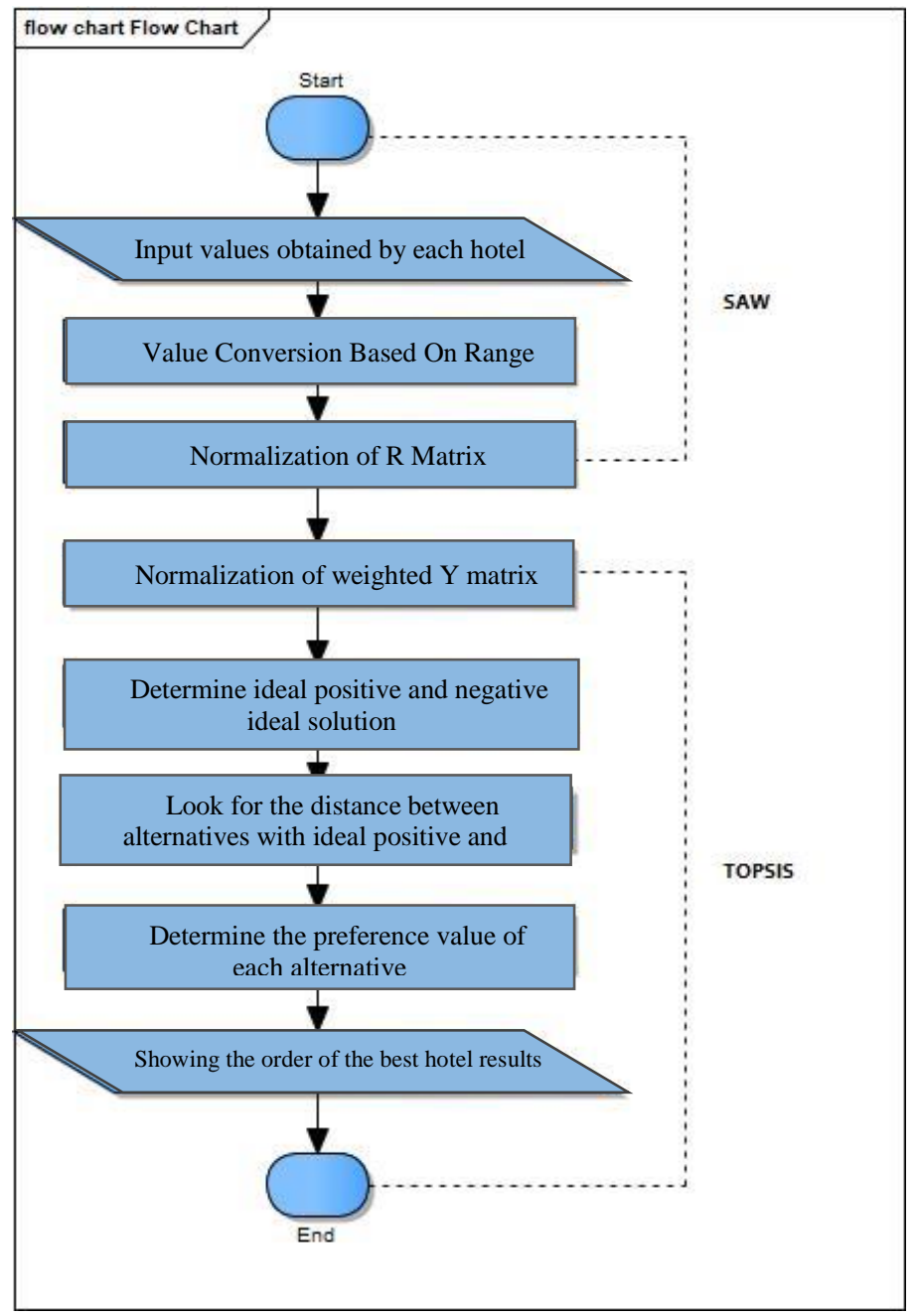

Figure 1. Flowchart of the SAW - TOPSIS Method

In Figure 1, it is explained that the stages of the decision support system (DSS) consist of 2 methods, namely, the SAW and TOPSIS methods. The process begins by using the SAW algorithm method where there are 3 processes, namely:

1. Inputting the value obtained by each hotel (alternative data, criteria data, weighting data).

2. Conversion of values based on range of values.

3. R normalization matrix

Then the process is continued by using the TOPSIS method where there are 5 processes, namely:

1. Normalization of weighted matrix $y$.

2. Determine positive ideal solutions and negative ideal solutions.

3. Look for distance between alternatives with ideal positive solutions and negative ideal solutions.

4. Determine the preference value of each alternative.

5. Sort the results of the best hotels.

\section{Decision Making Process}

Before starting the process, the user first enters the name / location of the hotel, the number of check-ins, the number of nights, the number of rooms and the number of people to look for hotels available on website. In this case, the researcher inputs the search with the keyword "Tangerang" with the date Check in July 5, 2018, 1 night, the number of rooms 2 and for 7 people. From the search for the hotel, there were 6 alternative hotels, namely:

1. FM7 Resort Hotel

2. Atria Residences Gading Serpong 
3. Siti Hotel Syariah Tangerang

4. Grand Serpong Hotel

5. Kinari Residence

6. Aviary Bintaro

Alternative hotel data with detailed criteria can be seen in table 4

Table 4 Alternative Data for Hotels

\begin{tabular}{|c|c|c|c|c|}
\hline No & Hotel Name & Price & Facilities & Class \\
\hline 1 & $\begin{array}{l}\text { FM7 Resort } \\
\text { Hotel }\end{array}$ & $\begin{array}{l}\text { IDR } \\
1,490,000\end{array}$ & $\begin{array}{l}\text { Bar / Pub, Business Center, Free Parking, Coffee } \\
\text { Shop, Private Staff, Door Guard, Valuable Storage } \\
\text { Box, Drug Store, Elevator, Free Airport Shuttle, } \\
\text { Free Shuttle, Karaoke, Laundry Service / Dry } \\
\text { Cleaning, Lounge, Meeting Facilities, Restaurants, } \\
\text { Building Bar, Room Service, Salon, Shop, Waiter } \\
\text { Parking Service, Wi-Fi in public areas, In-Room } \\
\text { Wifi; } \\
\text { Air Conditioning, Towel, Coffee / tea maker, Free } \\
\text { bottled mineral water, Desk, Free Toiletries, } \\
\text { Hairdryer, Hot and Cold Shower, Safe, Internet - } \\
\text { Wifi, Television LCD / plasma screen, Mirror, } \\
\text { Satellite / Cable TV, Slippers; } \\
\text { Parks, Indoor Swimming Pools, Jogging Places, } \\
\text { Massage, Saunas; }\end{array}$ & 4 \\
\hline 2 & $\begin{array}{l}\text { Atria } \\
\text { Residences } \\
\text { Gading } \\
\text { Serpong }\end{array}$ & $\begin{array}{l}\text { IDR } \\
577,480\end{array}$ & $\begin{array}{l}\text { 24-Hour Room Service, Charged Airport Shuttle, } \\
\text { Business Center, Free Parking, Coffee Shop, Door } \\
\text { Guard, Valuable Storage Box, Executive Room, } \\
\text { Free in-room Wifi, Laundry / Dry Cleaning Service, } \\
\text { Elevator, Luggage Storage, Meeting Facilities, } \\
\text { Restaurant, Room Service, Shops, Sundeck, Tours, } \\
\text { Wi-Fi in public areas, In-room wifi; } \\
\text { Air Conditioning, Towel Cover, Coffee / Tea } \\
\text { Maker, Free bottled mineral water, Wardrobe, Desk, } \\
\text { Free Toiletries, Hair Dryer, Hot and Cold Shower, } \\
\text { Safe, Internet - Wifi, } \\
\text { LCD television / plasma screen, Living Room, } \\
\text { Small Bar, Mirror, Satellite / Cable TV, Shower, } \\
\text { Slippers, Sofa Bed, Telephone, Television; } \\
\text { Park, Golf Course (on the spot), Massage, Outdoor } \\
\text { Pool, Spa; }\end{array}$ & 4 \\
\hline 3 & $\begin{array}{l}\text { Siti Hotel } \\
\text { Syariah } \\
\text { Tangerang }\end{array}$ & $\begin{array}{l}\text { IDR } \\
1,440,000\end{array}$ & $\begin{array}{l}\text { 24-Hour Room Service, Business Center, Free } \\
\text { Parking, Private Staff, Elevator, Free Airport } \\
\text { Shuttle, Laundry Service / Dry Cleaning, Meeting } \\
\text { Facilities, Restaurants, Room Service, In-Room } \\
\text { Wifi; } \\
\text { AC, Mirror, Television; }\end{array}$ & 3 \\
\hline 4 & $\begin{array}{l}\text { Grand Serpong } \\
\text { Hotel }\end{array}$ & $\begin{array}{l}\text { IDR } \\
1,100,000\end{array}$ & $\begin{array}{l}\text { 24-Hour Room Service, Airport Shuttle Charged, } \\
\text { Bar / Pub, Bar, Business Center, Free Parking, } \\
\text { Coffee Shop, Door Guard, Private Staff, Valuable } \\
\text { Storage Boxes, Lifts, Family Lounge, Free Wifi in } \\
\text { Lounge, Free Wifi in rooms, Laundry Services / Dry } \\
\text { Cleaning, Lifts, Lounges, Luggage Storage, } \\
\text { Meeting Facilities, Restaurants, Room Service, } \\
\text { Smoking Rooms are subject to availability, Wi-Fi in } \\
\text { public areas, In-Room Wifi; }\end{array}$ & 4 \\
\hline
\end{tabular}




\begin{tabular}{|c|c|c|c|c|}
\hline & & & $\begin{array}{l}\text { AC, Terrace, Chair, Coffee / tea maker, Free bottled } \\
\text { mineral water, Daily newspaper, Desk, Hairdryer, } \\
\text { Hot and Cold Shower, Safety deposit box, Internet - } \\
\text { Wifi (free), Ironing board on request, LCD } \\
\text { television / plasma screen, Small bar, Mirror, Non- } \\
\text { smoking rooms subject to availability, Satellite / } \\
\text { Cable TV, Slippers, Phones; } \\
\text { Sports Room, Massage, Outdoor Pool, Swimming } \\
\text { Pool (Children), Spa; }\end{array}$ & \\
\hline 5 & $\begin{array}{l}\text { Kinari } \\
\text { Residence }\end{array}$ & $\begin{array}{l}\text { IDR } \\
390,000\end{array}$ & $\begin{array}{l}\text { 24-Hour Room Service, Elevator, Family Relaxing } \\
\text { Room, Laundry Service / Dry Cleaning, Restaurant, } \\
\text { Wi-Fi in public areas, In-Room Wifi; } \\
\text { AC, Chair, Desk, Free Toiletries, Hot and Cold } \\
\text { Shower, Internet - Wifi, Kitchen Equipment, Small } \\
\text { Bar, Refrigerator, Satellite / Cable TV, Shower, } \\
\text { Smart TV, Television, Water Dispenser; }\end{array}$ & 3 \\
\hline 6 & Aviary Bintaro & $\begin{array}{l}\text { IDR } \\
2,009,412\end{array}$ & $\begin{array}{l}\text { 24-Hour Room Service, Baby Beds, Business } \\
\text { Centers, Coffee Shops, Valuable Storage Boxes, } \\
\text { Lifts, Family Relaxing Rooms, Laundry Services / } \\
\text { Dry Cleaning, Lounge, Meeting Facilities, } \\
\text { Restaurants, Building Bar, Wi-Fi in public areas, In- } \\
\text { room wifi; } \\
\text { Air Conditioning, Towel Cover, Coffee / Tea } \\
\text { Maker, Daily Newspaper, Dining Room, Free } \\
\text { Toiletries, Hair Dryer, Hot and Cold Shower, Safety } \\
\text { Deposit Box, Internet - Free Wifi, Television LCD / } \\
\text { Plasma Screen, Living Room, Small Bar, Mirror, } \\
\text { Non-smoking rooms subject to availability, Parquet } \\
\text { Floor, Satellite / Cable TV, Shower, Slippers, } \\
\text { Telephone, Television; } \\
\text { Parks, Sports Rooms, Indoor Swimming Pool, } \\
\text { Massage, Swimming Pool (Children); }\end{array}$ & 4 \\
\hline
\end{tabular}

Then from the Alternative Data obtained, the price and class values in the alternatives are converted according to the weight values in table 1 and table 3

For facility criteria, first calculated how many facilities a hotel has. The number of facilities of a hotel will be shared with the hotel with the highest number of facilities. In this case there are 6 hotels as an alternative. Of the 6 hotels, which have the highest number of facilities, namely Grand Serpong Hotel with 48 facilities. So in this calculation case the researcher concluded that the maximum facility is 48 . Then the criteria for a hotel facility can be calculated by the number of facilities of a hotel divided by 48 (maximum facilities). After the value of facility criteria is obtained, then it is continued with weighting according to table 5

Table 5 Compatibility Rating Tables of Each Alternative in Each Criteria

\begin{tabular}{|l|r|r|r|}
\hline \multicolumn{1}{|c|}{ Alternative } & \multicolumn{3}{c|}{ Criteria } \\
\hline FM7 Resort Hotel & Price (C1) & Facility (C2) & Class (C3) \\
\hline Atria Residences Gading Serpong & 3 & 5 & 4 \\
\hline Siti Hotel Syariah Tangerang & 2 & 5 & 4 \\
\hline Grand Serpong Hotel & 3 & 2 & 3 \\
\hline Kinari Residence & 3 & 5 & 4 \\
\hline Aviary Bintaro & 1 & 3 & 3 \\
\hline
\end{tabular}


The next process is to weight the preference (W) of each criterion. Determining the weight of each criterion using a Likert scale with a positive question scale format, namely:

Score $1=$ Very Important

Score 2 = Not Important

Score 3 = Quite Important

Score $4=$ Important

Score 5 = Very Important

The criteria for the first priority will be given a higher value than the criteria considered to have a lower priority. This weighting process is carried out by users according to their interests. In this case the researcher gives preference weights as follows: $\mathrm{C} 1=4, \mathrm{C} 2=5, \mathrm{C} 3=3$; After the weight values of each criterion are obtained, a normalization process is carried out which aims to make the weight values of each criterion normal and not to have a gap in the weight value between the criteria that is too high. The following formula for normalizing the weight of each criterion.

So that we get a weight value:

$$
\text { Ternormalized weights }=\frac{\text { Weights }}{\sum \text { Weights }}
$$

$$
\mathrm{W}=\{0.333 ; 0.4166 ; 0.25\}
$$

\section{Calculation of the SAW-TOPSIS Method SAW Method}

Step 1: Create Decision X Matrix from the data in table 5

$$
X=\left[\begin{array}{lll}
3 & 5 & 4 \\
2 & 5 & 4 \\
3 & 2 & 3 \\
3 & 5 & 4 \\
1 & 3 & 3 \\
4 & 5 & 4
\end{array}\right]
$$

Step 2: Make Normalization of the R Decision Matrix, using the formula

$$
\begin{gathered}
r_{i j}=\frac{x_{i j}}{\operatorname{Max}\left(x_{i j}\right)} \text { If } \mathbf{j} \text { is an attribute of Benefits. } \\
r_{i j}=\frac{\operatorname{Min}\left(x_{i j}\right)}{x_{i j}} \text { If } \mathbf{j} \text { is an attribute of Cost. }
\end{gathered}
$$

1. Price (cost)

$$
\begin{aligned}
& r_{11}=\frac{\min \{3,2,3,3,1,4\}}{3}=\frac{1}{3}=0.33 \\
& r_{21}=\frac{\min \{3,2,3,3,1,4\}}{2}=\frac{1}{2}=0.5 \\
& r_{31}=\frac{\min \{3,2,3,3,1,4\}}{3}=\frac{1}{3}=0.33 \\
& r_{41}=\frac{\min \{3,2,3,3,1,4\}}{3}=\frac{1}{3}=0.33 \\
& r_{51}=\frac{\min \{3,2,3,3,1,4\}}{1}=\frac{1}{1}=1 \\
& r_{61}=\frac{\min \{3,2,3,3,1,4\}}{4}=\frac{1}{4}=0.25
\end{aligned}
$$


2. Facilities (benefit)

$$
\begin{aligned}
& r_{12}=\frac{5}{\max \{5,5,2,5,3,5\}}=\frac{5}{5}=1 \\
& r_{22}=\frac{5}{\max \{5,5,2,5,3,5\}}=\frac{5}{5}=1 \\
& r_{32}=\frac{5}{\max \{5,5,2,5,3,5\}}=\frac{2}{5}=0.4 \\
& r_{42}=\frac{5}{\max \{5,5,2,5,3,5\}}=\frac{5}{5}=1 \\
& r_{52}=\frac{3}{\max \{5,5,2,5,3,5\}}=\frac{3}{5}=0.6 \\
& r_{62}=\frac{5}{\max \{5,5,2,5,3,5\}}=\frac{5}{5}=1
\end{aligned}
$$

3. Class (benefit)

$$
\begin{gathered}
r_{13}=\frac{4}{\max \{4,4,3,4,3,4\}}=\frac{4}{4}=1 \\
r_{23}=\frac{4}{\max \{4,4,3,4,3,4\}}=\frac{4}{4}=1 \\
r_{33}=\frac{3}{\max \{4,4,3,4,3,4\}}=\frac{3}{4}=0.75 \\
r_{43}=\frac{4}{\max \{4,4,3,4,3,4\}}=\frac{4}{4}=1 \\
r_{53}=\frac{3}{\max \{4,4,3,4,3,4\}}=\frac{3}{4}=0.75 \\
r_{63}=\frac{4}{\max \{4,4,3,4,3,4\}}=\frac{4}{4}=1
\end{gathered}
$$

Obtained the R decision matrix shown in table 6

Table 6. R Normalization Matrix Table

\begin{tabular}{|l|l|l|l|}
\hline \multicolumn{1}{|c|}{ Alternative } & Price & Facilities & Class \\
\hline FM7 Resort Hotel & 0.33 & 1 & 1 \\
\hline Atria Residences Gading Serpong & 0.5 & 1 & 1 \\
\hline Siti Hotel Syariah Tangerang & 0.33 & 0.4 & 0.75 \\
\hline Grand Serpong Hotel & 0.33 & 1 & 1 \\
\hline Kinari Residence & 1 & 0.6 & 0.75 \\
\hline \hline Aviary Bintaro & $\mathbf{0 . 2 5}$ & $\mathbf{1}$ & $\mathbf{1}$ \\
\hline
\end{tabular}


To test whether there are differences in the calculation of SAW with SAW - TOPSIS, the researcher tries to continue the calculation of SAW to the end.

$$
\begin{aligned}
& \mathrm{V}_{1}=(0.333 * 0.33)+(0.4166 * 1)+(0.25 * 1)=0.7776 \\
& \mathrm{~V}_{2}=(0.333 * 0.5)+\left(0.4166^{*} 1\right)+\left(0.25^{* 1} 1\right)=0.8331 \\
& \mathrm{~V}_{3}=(0.333 * 0.33)+\left(0.4166^{*} 0.4\right)+(0.25 * 0.75)=0.46514 \\
& \mathrm{~V}_{4}=(0.333 * 0.33)+(0.4166 * 1)+\left(0.25^{*} 1\right)=0.7776 \\
& \mathrm{~V}_{5}=(0.333 * 1)+(0.4166 * 0.6)+(0.25 * 0.75)=0.77046 \\
& \mathrm{~V}_{6}=(0.333 * 0.25)+(0.4166 * 1)+(0.25 * 1)=0.74985
\end{aligned}
$$

A larger $\mathrm{Vi}$ value indicates the alternative $\mathrm{Ai}$ is the best alternative. In the results of SAW calculations, it is seen that the biggest Vi value is V2 (Atria Residences Gading Serpong). Followed by V1 (FM7 Resort Hotel), V4 (Grand Serpong Hotel), V5 (Kinari Residence), V6 (Aviary Bintaro) and finally V3 (Siti Syariah Hotel Tangerang).

\section{TOPSIS Method}

Step 3: Normalization of the Y Weighted Matrix based on the value of each element in the normalized R matrix obtained in the SAW method using the equation: $y \_i j=w \_i$ r_ij. So that:

$$
\begin{aligned}
& \mathrm{y}_{11}=0.333 * 0.33=0.111 \\
& \mathrm{y}_{12}=0.4166 * 1=0.416 \\
& \mathrm{y}_{13}=0.25 * 1=0.25 \\
& \mathrm{y}_{21}=0.333 * 0.5=0.1665 \\
& \mathrm{y}_{22}=0.4166 * 1=0.4166 \\
& \cdots \cdots
\end{aligned}
$$

Then the Y weighted normalized matrix results are shown in Table 7

Table 7. Table of Y Weighted Matrices

\begin{tabular}{|l|l|l|l|}
\hline \multicolumn{1}{|c}{ Alternative } & \multicolumn{3}{c|}{ Criteria } \\
\hline & \multicolumn{1}{|c|}{ Price } & Fasilities & \multicolumn{1}{c|}{ Class } \\
\hline FM7 Resort Hotel & 0.111 & 0.4166 & 0.25 \\
\hline Atria Residences Gading Serpong & 0.1665 & 0.4166 & 0.25 \\
\hline Siti Hotel Syariah Tangerang & 0.111 & 0.16664 & 0.1875 \\
\hline Grand Serpong Hotel & 0.111 & 0.4166 & 0.25 \\
\hline Kinari Residence & 0.333 & 0.24996 & 0.1875 \\
\hline Aviary Bintaro & 0.08325 & 0.4166 & 0.25 \\
\hline
\end{tabular}

Step 4: Determine Ideal Positive $(\mathrm{A}+)$ Solutions and Ideal Negative Solutions (A-).

1. Determine the Ideal Positive Solution $(\mathrm{A}+)$, with the equation: $\mathrm{A}^{\wedge}+=\left(\mathrm{y}_{-} 1^{\wedge}+, \mathrm{y}_{-} 2^{\wedge}+, \ldots, \mathrm{y}_{-} \mathrm{n}^{\wedge}+\right)$;

$y_{1}^{+}=\max (0.111 ; 0.1665 ; 0.111 ; 0.111 ; 0.333 ; 0.08325)=0.333$

$y_{2}^{+}=\max (0.4166 ; 0.4166 ; 0.16664 ; 0.4166 ; 0.24996 ; 0.4166)=0.4166$

$y_{3}^{+}=\max (0.25 ; 0.25 ; 0.1875 ; 0.25 ; 0.1875 ; 0.25)=0.25$

Result:

$$
A^{+}=(0.333 ; 0.4166 ; 0.25)
$$

2. Determine the Ideal Negative Solution (A-), with the equation: $\mathrm{A}^{\wedge}{ }_{-}=\left(\mathrm{y}_{-} 1^{\wedge} \mathcal{-}_{-}, \mathrm{y}_{-} 2^{\wedge}{ }_{-}, \ldots, \mathrm{y}_{-} \mathrm{n}^{\wedge}-\right)_{\text {; }}$

$y_{1}^{-}=\min (0.111 ; 0.1665 ; 0.111 ; 0.111 ; 0.333 ; 0.08325)=0.08325$

$y_{2}^{-}=\min (0.4166 ; 0.4166 ; 0.16664 ; 0.4166 ; 0.24996 ; 0.4166)=0.16664$

$y_{3}^{-}=\min (0.25 ; 0.25 ; 0.1875 ; 0.25 ; 0.1875 ; 0.25)=0.1875$

Result:

$$
A^{-}=(0.08325 ; 0.16664 ; 0.1875)
$$

Step 5: Calculating the Distance of Ideal Positive (D +) Solutions and Ideal Negative Solutions (D -). 
1. Distance Ideal Ideal Solution $(\mathrm{D}+)$, with the equation:

$$
\begin{gathered}
D_{i}^{+}=\sqrt{\sum_{i=1}^{n}\left(y_{i}^{+}-y_{i j}\right)^{2}} \\
D_{1}^{+}=\sqrt{(0.333-0.111)^{2}+(0.4166-0.4166)^{2}+(0.25-0.25)^{2}}=0.222 \\
D_{2}^{+}=\sqrt{(0.333-0.1665)^{2}+(0.4166-0.4166)^{2}+(0.25-0.25)^{2}}=0.1665 \\
D_{3}^{+}=\sqrt{(0.333-0.111)^{2}+(0.4166-0.16664)^{2}+(0.25-0.1875)^{2}}=0.340103295
\end{gathered}
$$

2. Distance Negative Ideal Solution (D -), with the equation:

$$
\begin{aligned}
& D_{i}^{-}=\sqrt{\sum_{i=1}^{n}\left(y_{i j}-y_{i}^{-}\right)^{2}} \\
& D_{1}^{-}=\sqrt{(0.111-0.08325)^{2}+(0.4166-0.16664)^{2}+(0.25-0.1875)^{2}}=0.259145353 \\
& D_{2}^{-}=\sqrt{(0.1665-0.08325)^{2}+(0.4166-0.16664)^{2}+(0.25-0.1875)^{2}}=0.270770778 \\
& D_{3}^{-}=\sqrt{(0.111-0.08325)^{2}+(0.16664-0.16664)^{2}+(0.1875-0.1875)^{2}}=0.02775
\end{aligned}
$$

The results of the distance of the ideal positive solution and the ideal negative solution can be shown in table 8

Table 8. Distance Ideal Positive (D +) Solutions and Ideal Negative Solutions (D-)

\begin{tabular}{|l|l|l|}
\hline \multicolumn{1}{|c|}{ Alternative } & \multicolumn{1}{|c|}{ Positive Distance D + } & \multicolumn{1}{c|}{ Negative Distance D- } \\
\hline FM7 Resort Hotel & 0.222 & 0.259145353 \\
\hline Atria Residences Gading Serpong & 0.1665 & 0.270770778 \\
\hline Siti Hotel Syariah Tangerang & 0.340103295 & 0.02775 \\
\hline Grand Serpong Hotel & 0.222 & 0.259145353 \\
\hline Kinari Residence & 0.177975109 & 0.26328176 \\
\hline Aviary Bintaro & 0.24975 & 0.257655296 \\
\hline
\end{tabular}

Step 6: Determine the preference value for each alternative, with the equation:

$$
\begin{aligned}
& \qquad V_{i}=\frac{D_{i}^{-}}{D_{i}^{+}+D_{i}^{-}} \\
& V_{1} \text { FM7 Resort Hotel }=\frac{0.259145353}{0.222+0.259145353}=0.538601 \\
& V_{2} \text { Atria Residences Gading Serpong }=\frac{0.270770778}{0.1665+0.270770778}=0.619229 \\
& V_{3} \text { Siti Hotel Syairah Tangerang }=\frac{0.02775}{0.340103295+0.02775}=0.075438 \\
& V_{4} \text { Grand Serpong Hotel }=\frac{0.259145353}{0.222+0.259145353}=0.538601 \\
& V_{5} \text { Kinari Residence }=\frac{0.26328176}{0.177975109+0.26328176}=0.596663 \\
& V_{6} \text { Aviary Bintaro }=\frac{0.257655296}{0.24975+0.257655296}=0.50779
\end{aligned}
$$

The results are described in table 9 
Table 9. Preference Values for Each Alternative

\begin{tabular}{|c|l|c|c|}
\hline No & \multicolumn{1}{|c}{ Alternative } & \multicolumn{1}{c|}{ Preference Value } & Ranking \\
\hline $\boldsymbol{V}_{\mathbf{1}}$ & FM7 Resort Hotel & 0.538600968 & 3 \\
\hline $\boldsymbol{V}_{\mathbf{2}}$ & Atria Residences Gading Serpong & 0.619229072 & 1 \\
\hline $\boldsymbol{V}_{\mathbf{3}}$ & Siti Hotel Syariah Tangerang & 0.075437682 & 6 \\
\hline $\boldsymbol{V}_{\mathbf{4}}$ & Grand Serpong Hotel & 0.538600968 & 4 \\
\hline $\boldsymbol{V}_{\mathbf{5}}$ & Kinari Residence & 0.596663254 & 2 \\
\hline $\boldsymbol{V}_{\mathbf{6}}$ & Aviary Bintaro & 0.507789923 & 5 \\
\hline
\end{tabular}

A larger preference value ( $\mathrm{Vi}$ ) indicates that alternative (Ai) is the best alternative. It can be seen that from table 9 the greatest preference value is located at the Atria Residences Gading Serpong hotel so that the Atria Residences Gading Serpong hotel can be used as an alternative choice in hotel selection.

In this case, it is also seen that the calculation of the SAW method with SAW-TOPSIS produced the same best alternative, namely the Atria Residences Gading Serpong hotel and the alternative with the same lowest value, Siti Hotel Syariah Tangerang. However, in the alternative 2nd rank there are alternative differences from the calculation of the 2 methods.

\section{Application Interface}

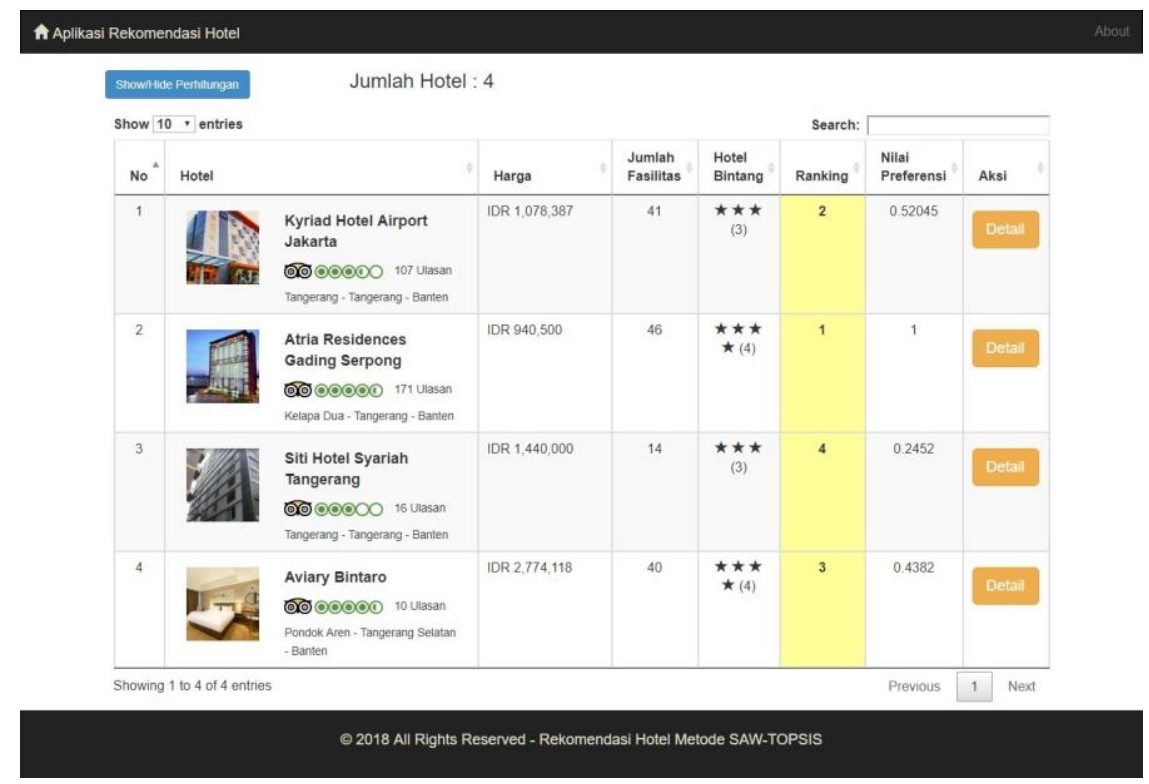

Figure 2. Hotel Recommendation Result Page

It is a page that appears after a user clicks the Calculate DSS button on the Hotel Search Results page. This page displays the results of the hotel approval calculation. Hotels with the highest ranking (rank 1) are the main considerations of the results of the calculation of this recommendation. Users can also sort each column by clicking on the top column. Button details to display detailed hotel information selected. Display / Hide Calculations which, if clicked, will display the process of calculating the SAW-TOPSIS method.

\section{CONCLUSIONS}

The hotel recommendation system application with the SAW - TOPSIS method has been successfully created and can help users find hotels according to the desired criteria. Users can find information on a hotel such as price, location, address, class, facilities, rating and image of the hotel.

You can further develop it by ordering or booking the hotel directly and adding features to the nearest hotel. And add other criteria in the next study. 


\section{REFERENCES}

[1] Badan Pusat Statistik. (2018). Tabel Dinamis. Diambil dari : https://www.bps.go.id/site/pilihdata.html (30 April 2018)

[2] Hidayat, Muslim dan M. Alif Muafiq Baihaqi. (2016). "Sistem Pendukung Keputusan Untuk Pemilihan Hotel Dengan Simple Additive Weighting (SAW) Berbasis Web." Seminar Nasional Teknologi Informasi dan Multimedia, Vol 4, no. 1 hal: 61-66.

[3] Kementrian Pariwisata Republik Indonesia. (2018). Statistik Pariwisata. Diambil dari: http://www.kemenpar.go.id/asp/index.asp (30 April 2018)

[4] Kendall, Kenneth E. dan Julie E. Kendall. (2010). Analisis dan Perancangan Sistem. Jakarta: PT INDEKS.

[5] Nofriansyah, Dicky. (2015). Konsep Data Mining Vs Sistem Pendukung Keputusan. Yogyakarta: Deepublish.

[6] Putri, Lisa Septian, Nurul Hidayat dan Suprapto. (2018). "Sistem Pendukung Keputusan Pemilihan Mitra Jasa Pengiriman Barang menggunakan Metode Simple Additive Weighting (SAW) - Technique for Other Reference by Similarity to Ideal Solution (TOPSIS) di Kota Malang." Jurnal Pengembangan Teknologi Informasi dan Ilmu Komputer, Vol 2 No 3 hal : 1219-1226.

[7] Ramadhani, Mochamed Fajar. (2015). "Pembangunan Aplikasi Informasi, Pengaduan, Kritik, dan Saran Seputar Kota Cimahi Pada Platform Android." Jurnal Ilmiah Komputer dan Informatika (KOMPUTA).

[8] Rasyid, Abdul dan Septya Maharani. (2016). "Implementasi Technique for Order Preferences by Similary to Ideal Solution (TOPSIS) Pada Seleksi Asisten Laboratorium (Studi kasus: Laboratorium RPL FMIPA Universitas Mulawarman)." Jurnal Informatika Mulawarman, hal: 48-53.

[9] Sutrisno, Denny. (2013). "Pengaruh Jumlah Obyek Wisata, Jumlah Hotel, Dan PDRB Terhadap Retribusi Pariwisata Kabupaten / Kota Di Jawa Tengah." Economics Development Analysis Journal, Vol 2 No 4 hal : 435 445.

[10] Budi, Agung Permana. (2013). Manajemen Marketing Perhotelan. Yogyakarta: CV Andi Offset.

[11] Riki, R., \& Giap, Y. C. (2018). Design of Acceptance Decision Support System for New Employees in the Technician Position Using AHP and TOPSIS Methods at CV. Techindo Global Solution. bit-Tech, 1(2), 21-29. 